\title{
The Evolution of the Approach to the Integration of Immigrants in Poland
}

\begin{abstract}
The aim of the paper is to present issues related to the approach to the integration of immigrants in Poland in the last three decades. The article is seeking an answer to the question of how the approach to immigrant integration has evolved? Does the evolving approach reflect the rising tide of change taking place in Europe? First, the article discusses the issues of migration to Poland. It is essential to consider cultural conditions related to the national identity and migration history of a given country in an attempt to explain the evolution of the integration policy. The subsequent parts analyze the Polish integration policy until 2015 and the integration policy after 2015. The results of the research show that in Poland, the approach to the integration of immigrants has evolved in a short time: from the "strategy of abandonment" to "integration" understood as a two-way process of adaptation to the concept of assimilation.
\end{abstract}

Keywords: Immigrants, Integration, Concepts, Integration Policy, Poland

\section{Introduction}

The migration and refugee crisis in Europe has made integration policy issues a priority. The effectiveness of integration policies often determines attitudes towards immigration later on. For this reason, the integration policy should be treated as an issue at least as important as immigration policy. ${ }^{1} \mathrm{~A}$ measure of the effectiveness of integration policy would be how

^ Lucyna Rajca-Jan Kochanowski University of Kielce, e-mail: lucyna.rajca@ujk. edu.pl, ORCID: 0000-0002-3947-1729.

${ }^{1}$ M. Duszczyk, M. Pachocka, D. Pszczółkowska, Introduction, in: Relations between Immigration and Integration Policies in Europe. Challenges, Opportunities and Perspectives in Selected EU Member States, eds. M. Duszczyk, M. Pachocka, D. Pszczółkowska, 
the influx of migrants influenced the level of social cohesion in a given country. For instance, a decision to give immigrants access to the labour market should be based on the country's ability to integrate newcomers in to the host society. ${ }^{2}$

In the nineties of the previous century, many concepts of immigrant integration, which were to replace the multicultural policy, became popular in Europe. The concept of "integration", understood as a two-way process of adaptation of immigrants involving the change not only in the values, norms and behaviors of newcomers but also members of the host society, gained immense popularity. ${ }^{3}$ In order to define the policy of integration of immigrants, the European debate used such terms as "intercultural" or "post-multicultural". ${ }^{4}$ The concept of multiculturalism embraces the ideas of coexistence, while interculturalism emphasizes the importance of cultural dialogue and interactions between different groups, ${ }^{5}$ which is important from the point of view of social cohesion. It is argued in the literature that, as a result of the criticism of multiculturalism, there has been a return to assimilationist policies and that the approval of neoassimilation tendencies permeates the current discourse in Europe. ${ }^{6}$ The neo-assimilation approach emphasizes that the incorporation of immigrant groups also entails a change and acceptance of the mainstream of society. The "neo-assimilation" or "post-multicultural" model is based not only on the recognition of diversity, but also on the re-affirmation of a strong national identity through integration and language courses, citizenship exams, etc. that have appeared in European countries. ${ }^{7}$

Since the beginning of the 21 st century, governments in Western

London 2020, pp. 3-4.

${ }^{2}$ M. Duszczyk, M. Pachocka, D. Pszczółkowska, Conclusion, in: Relations between Immigration and Integration Policies in Europe. Challenges, Opportunities and Perspectives in Selected EU Member States, eds. M. Duszczyk, M. Pachocka, D. Pszczółkowska, London 2020, pp. 224-225.

${ }^{3}$ European Commission, Communication on Immigration, Integration and Employment, $\operatorname{COM}(2003) 336$ final.

${ }_{4}^{4}$ M. Schiller, Paradigmatic Pragmatism and the Politics of Diversity, "Ethnic and Racial Studies", no. 38(7)/2015, pp. 1120-1136.

5 F. Anthias, Moving beyond the fanus face of integration and diversity discourses: towards an intersectional framing, "The Sociological Review", no. 61(2)/2013, pp. 323-343.

${ }^{6}$ M. Ambrosini, P. Boccagni, Urban Multiculturalism beyond the 'Backlash': New Discourses and Different Practices in Immigrant Policies across European Cities, "Journal of Intercultural Studies”, no. 36(1)/2015, pp. 35-53.

7 S. Vertovec, Towards post-multiculturalism? Changing communities, conditions and contexts of diversity, "International Social Science Journal", no. 61(199)/2010, pp. 83-95. 
Europe that adopted a multicultural approach have started moving away from it, placing a strong emphasis on civic integration. The concept of civic integration involves the active inclusion of immigrants into the economic, political and social mainstream. Newcomers are required to learn the language, history, culture, institutions and standards of the host country and pass citizenship tests. ${ }^{8}$ The literature indicates that civic integration programs are potentially illiberal and assimilative in nature in relation to immigrants. ${ }^{9}$ They are part of the broader trend of creating more centralized and repressive and bureaucratic policies for the integration of immigrants and less related to solving practical problems or addressing specific needs. ${ }^{10}$ The migration and refugee crisis of 2015 resulted in the tightening of internal immigration and integration policies in EU countries, including Germany, France and the Netherlands. The main goal was to secure the interests of the host societies. ${ }^{11}$

The aim of the article is to present issues related to the approach to the integration of immigrants in Poland in the last three decades. The article is seeking an answer to the question of how the attitude to immigrant integration has evolved? Does the evolving approach reflect the rising tide of change taking place in Europe? First, the paper presents the scale of migration to Poland. It is essential to consider cultural conditions related to the national identity and migration history of a given country in an attempt to explain the evolution of the integration policy. The subsequent parts analyze the Polish integration policy until 2015 and the integration policy after 2015. Finally, the paper addresses research questions and formulates conclusions. The study employs the institutional and legal method and one of the quantitative methods - descriptive statistics. It is based on legal acts, documents, statistical data and literature on the subject.

\section{Immigrants in Poland}

Since the Second World War, Polish people have not experienced the presence of numerous national, ethnic, or religious groups. The difficulties

8 K. Banting, W. Kymlicka, Is There Really a Backlash Against Multiculturalism Policies? New Evidence from the Multiculturalism Policy Index, Universitat Pompeu Fabra, Working Paper Series, no. 14/2012, p. 5.

9 C. Joppke, The Role of the State in Cultural Integration. Trends, Challenges and Ways Ahead, Washington 2012.

10 D. Gebhardt, When the state takes over: civic integration programmes and the role of cities in immigrant integration, "Journal of Ethnic and Migration Studies", vol. 42(5)/2016, p. 754.

11 J. Ślęzak, Polityka migracyjna Unii Europejskiej a problem integracji imigrantów w Niemczech, Francji i Holandii, „Cywilizacja i Polityka”, no. 16(16)/2018, pp. 397-400. 
of migrating and settling in other countries, characteristic of the countries of the former Eastern bloc, limited the phenomenon of migration. After a period of massive post-war migrations, there was a period known as "immigration shutdown". ${ }^{12}$ For this reason, Polish public opinion did not engage in the presence of foreigners thus and did not constitute a political problem. The concept of "integration" was not, however, completely new, neither in national policy nor in social research. It particularly concerned post-war repatriates mostly settled in northern and western Poland. The beginning of the nineties of the previous century was a breakthrough in the migration processes. The borders were opened for both Poles and foreigners. Despite this, the scale of migration to Poland remained marginal. At the end of 2013, 121,219 foreigners had residence permits in Poland, which constituted $0.3 \%$ of the Polish population. The dynamic increase in migration to Poland began only in 2014, and its main reason was the outbreak of the conflict in eastern Ukraine, moreover, the liberalization of regulations legalizing the stay of foreigners in the Republic of Poland, the introduction of simplified employment procedures and many other factors. According to Eurostat, out of all EU countries, in 2018 and 2019 Poland issued the largest number of first residence permits to citizens of non-EU countries (2019 - 724.4 thousand or 24 percent of the EU total), a lot more than such established immigration countries as Germany, Great Britain, Spain, France, Italy, the Netherlands and Sweden. ${ }^{13}$ Such a massive influx of immigrants in the last few years is an entirely new phenomenon bringing unprecedented challenges. It should be noted, however, that most residence permits in Poland were issued for a period not exceeding one year. It might be expected that the current inflow of foreigners to Poland, mainly temporary workers, will in the coming decades take the form of long-term immigration - similarly to other European countries. ${ }^{14}$

According to GUS (Central Statistical Office) estimates, as of December 31, 2019, there were 2.1 million foreigners living in Poland. Most of them were of Ukrainian citizenship (1.35 million), followed by citizens of Belarus (105.4 thousand), Germany (77 thousand), Moldova (37.3 thousand),

12 S. Łodziński, A. Grzymała-Kazłowska, Koncepcje, badania i praktyki integracji imigrantów. Doświadczenia polskie w europejskim kontekście, „Studia Migracyjne - Przegląd Polonijny", no. 37/2011, z. 2(140), p. 28.

13 Eurostat, Residence permits - statistics on first permits issued during the year, November 2020, https://ec.europa.eu/eurostat/statistics (access 30.12.2020).

${ }^{14} \mathrm{M}$. Okólski, D. Wach, Immigration and integration policies in the absence of immigrants. A case study of Poland, in: Relations between Immigration and Integration Policies in Europe. Challenges, Opportunities and Perspectives in Selected EU Member States, eds. M. Duszczyk, M. Pachocka, D. Pszczółkowska, London 2020, p. 147. 
Russia (37 thousand), India (33.1 thousand), Georgia (27.9 thousand), Vietnam (27.4 thousand), Turkey (25 thousand), China (23.4 thousand). ${ }^{15}$ The vast majority of foreigners come from countries neighboring Poland. This translates into the immigrant's cultural similarity and the lack of strong adaptation tensions. Other foreigners originate from cultures different from Polish and have various religious affiliation. Nevertheless, the research results do not indicate any significant problems with their integration into Polish society. ${ }^{16}$ It is worth adding that the influx of foreigners to Poland was primarily of a gainful nature, and immigrants are people with relatively high education.

Refugees and people covered by other forms of international protection constitute a small group as compared to other groups of migrants to Poland. In the years 1990-2015, over 135,000 foreigners applied for refugee status. Only about 4.5 thousand people were allowed to settle in Poland (3.5\%), and about 15,000 were granted temporary protection or temporary tolerated stay. ${ }^{17}$ In the following years (2016-2019), 25,600 foreigners applied for refugee status, and 1,900 people were provided with international protection. ${ }^{18}$ It is likely that a considerable number of these people left the territory of the country, and Poland was only a transit country when travelling to Western Europe. Citizens of Russia have filed the most applications for international protection in Poland. Very few refugees come from what is known as the Islamic State. Poland is classified as a country not directly affected by the migration crisis.

Despite the dynamic increase in the number of immigrants in recent years, Poland is still one of the EU countries with the lowest percentage of foreigners in the total population - this indicator in 2019 was $0.8 \%$. For comparison, in Slovakia, this percentage was $1.4 \%$, in Hungary $1.8 \%$, in the Czech Republic 5.2\%, in France 7.3\%, and in Germany $12.2 \% .{ }^{19}$ Since the end of World War II, Poland has remained an ethnically homogeneous state. The ethnic homogeneity of Poland significantly hinders the creation

15 GUS, Populacja cudzoziemców w Polsce w czasie COVID-19, https://stat.gov.pl/ statystyki (access 10.12.2020).

16 Oświadczenie Komitetu Badań nad Migracjami PAN, http://www.kbnm.pan. pl/42-uncategorised/109-oswiadczenie-komitetu-badan-nad-migracjami-pan (access 20.12.2020).

17 Urząd do spraw Cudzoziemców, Naptyw cudzoziemców ubiegających się o objęcie ochrona międzynarodowa do Polski w latach 2009-2015, https://udsc.gov.pl/statystyki/ raporty-specjalne/ochrona-miedzynarodowa-trendy/ (access 29.12.2020).

${ }_{18}$ Asylum seekers and beneficiaries of international protection in V4 Countries. (Updated Report), https://www.isp.org.pl (access 10.10.2020).

19 Eurostat, Migration and migrant population statistics pl, https://ec.europa.eu/eurostat/statistics-explained/pdfscache/14236.pdf (access 12.12.2020). 
and implementation of the policy of integration of foreigners.

\section{Integration Policy Until 2015}

Due to the marginal scale of immigration and the lack of strong ethnic and cultural tensions, national authorities in Poland did not show interest in the integration of immigrants and the issues related to it. The issues of immigrant integration were not included in the programs and discussions of political parties (with the exception of support for repatriates). Even after Poland joined the EU, politicians and public opinion were focused more on the economic emigration of Poles to the countries of the "old" EU than on the immigration of foreigners and their integration. ${ }^{20}$ In assessing the model of immigrant integration, Aleksandra GrzymałaKazłowska and Agnieszka Weinar stated in 2006 that "Poland does not promote either multiculturalism or interculturalism". They proposed to define the Polish integration policy as "assimilation by abandonment". ${ }^{21}$ In 2010, Dorota Szelewa described the Polish model of immigrant integration as "marginal, with elements of the insurance system", using "an abandonment strategy". ${ }^{22}$ Research on the practices of integration in Poland against the background of the experience of Western countries, in general, indicates the provisional, chaotic and changeable activities in various areas of integration of foreigners. ${ }^{23}$

The state pursued integration policy only towards repatriates ${ }^{24}$ and people granted international protection. One should mention here the introduction of individual integration programs (henceforth referred to as IPI) in 2000, which at the beginning of this century became the first stable instrument of the state's integration policy. Foreigners who acquired the refugee status or were given subsidiary protection obtained the right to apply to the poviat (county) starost for an individual integration program (IPI). The programs are implemented by poviat (county) family assistance centers (local government organizational unit) and supervised by the

${ }^{20}$ M. Duszczyk, M. Góra, Active Inclusion of Immigrants in Poland, IZA Discussion Paper No. 6427, Bonn 2012.

21 A. Grzymała-Kazłowska, A. Weinar, The Polish Approach to Integration, "Canadian Diversity", vol. 5(1)/2006.

22 D. Szelewa, Model integracji spotecznej imigrantów z krajów trzecich: dostęp do ustug spotecznych i przeglad polityki spotecznej, Raporty i Analizy, Warsaw 2010, p. 29.

23 S. Łodziński, A. Grzymała-Kazłowska, op.cit., pp. 11-39.

${ }^{24}$ Ustawa $\mathrm{z}$ dnia 9 listopada 2000 r. o repatriacji (Dz.U. 2000 no. 106, item 1118 with subsequent amendments); Ustawa z dnia 7 września 2007 r. o Karcie Polaka (Dz.U. 2018 item 1272 i 1669 with subsequent amendments). Pursuant to the Act on the Polish Charter, all citizens of the former Soviet Union who declared and could prove that they belong to the Polish nation could receive the Polish Charter, which gives foreigners access to the labour market and education on conditions similar to Polish citizens. 
Minister of Family, Labour and Social Policy. Assistance under the IPI depends - at least in theory - on active participation in the integration program and fulfilling the obligations related to the integration contract. Although the effectiveness of IPI is often questioned, as Dominik Wach emphasizes, it has become "a peculiar axis of institutional integration in Poland and further solutions were produced around it". 25

Poland did not carry out any active integration measures related to the remaining foreigners, except for the co-financing of projects implemented under the European Fund for the Integration of Third-Country Nationals. These projects, implemented mainly by non-governmental organizations (e.g. legal and professional counseling, educational projects, including language courses, cultural projects), often in public-private partnerships, were addressed both to third-country nationals and the host society (bidirectional integration). It is worth mentioning here that in 2015-2019, competitions for co-financing projects of non-governmental organizations under the Asylum, Migration and Integration Fund (AMIF) were canceled or suspended. As a result, most immigrant NGOs have been forced to cut back on their activities or even end their programs. ${ }^{26}$

The impulse to create the integration policy in Poland was the implementation in 2009 of the European Fund for the Integration of Third-Country Nationals. The fund, which was to supplement actions taken by the state, in the case of Poland, was almost entirely responsible for the nature of integration activities. ${ }^{27}$ Similar to other new member states, Poland has taken over the acquis communautaire in the area of migration and integration, not attaching considerable importance to the needs and specificity of the country. ${ }^{28}$ The main strategic document on migration and integration of immigrants was the Polityka migracyjna Polski - stan obecny i postulowane dziatania (Polish Migration Policy - current state and proposed actions), adopted by the Council of Ministers in July 2012. According to this document, integration policy was to be created at the central level, while local authorities and non-governmental organizations were to take care of its implementation, with the key importance of European funds. ${ }^{29}$ It specified the groups of foreigners that integrate with

25 D. Wach, Ewolucja polskiej polityki integracji cudzoziemców po 1989 roku, in: Polityka migracyjna w obliczu wspótczesnych wyzwań. Teoria i praktyka, eds. H. Chałupczak et al., Lublin 2018, p. 355.

${ }^{26}$ M. Okólski, D. Wach, op.cit., p. 162.

27 Ministerstwo Pracy i Polityki Społecznej, Polska polityka integracji cudzoziemców - zatożenia i wytyczne, Projekt, Warszawa, 25.09.2013, p. 17.

${ }_{28}$ M. Pawlak, Imitacja przy tworzeniu polskiej polityki integracji cudzoziemców, „Studia Migracyjne - Przegląd Polonijny”, no. 39(3)/2013, pp. 97-121.

${ }_{29}$ Polityka migracyjna Polski - stan obecny i postulowane dziatania, Dokument przy- 
the Polish society relatively easier and therefore should be privileged in terms of their admission. However, many issues of critical importance have not been addressed, including the model of immigrant integration in Polish society. ${ }^{30}$ Poland's immigration strategy focused primarily on filling the labour market shortages by hiring short-term foreign workers who were not subject to integration programs. The model of immigrant integration was presented in the draft document Polska polityka integracji cudzoziemców - zatożenia $i$ wytyczne (Polish policy on the integration of foreigners - assumptions and guidelines), presented in September 2013 by the Ministry of Labour and Social Policy, which is the leading institution in creating the policy of integration of foreigners in Poland. It was assumed that "integration is a complex and dynamic two-way process, involving both foreigners and the host society, the goal of which is full and equal membership of foreigners in the society of the host country". ${ }^{31}$ The aim of the integration was to make it possible for a foreigner to live independently in Poland. The emphasis was placed on the economic dimension of integration. The extension of the integration policy to include categories of foreigners other than refugees and repatriates was a novelty in Poland.

To sum up, the creation of the integration policy until 2015 was largely inspired by EU regulations and funds and was carried out in an evolutionary, technocratic, non-politicized and imitative manner, which facilitated the process of Europeanization of the introduced solutions. ${ }^{32}$

\section{Integration Policy After 2015}

In Poland, the migration and refugee crisis of 2015-2016 contributed to the extreme politicization of migration issues. The crisis coincided with the parliamentary elections and the change of government in Poland and caused regression rather than further development of integration policy. The assumptions resulting from the above-mentioned strategic documents did not enter the implementation phase, and in 2016 they were made void by the right-wing conservative government of Law and Justice. The crisis and the change of rhetoric in politics contributed to the creation of an anti-immigration climate in Poland and unfavorable conditions

jęty przez Radę Ministrów w dniu 31 lipca 2012, pp. 39, 72.

${ }_{30}$ M. Duszczyk, Polska polityka imigracyjna a rynek pracy, Warszawa 2012, p. 15.

${ }^{31}$ Polityka migracyjna Polski - stan obecny..., op.cit.

32 Cf.: S. Łodziński, M. Szonert, „Niepolityczna polityka”? Ksztattowanie się polityki migracyjnej w Polsce w latach 1989-2016 (kwiecień), CMR Working Papers, no. 90/148, Warsaw 2016, p. 22. 
for the integration of foreigners. ${ }^{33}$ Support for accepting refugees from the Middle East and Africa fell by nearly 20 percentage points within a few months. According to CBOS (Centre for Public Opinion Research) research, in May 2015, 53\% of respondents were against accepting refugees from this region, while in April 2016 this percentage increased to $71 \%$. In 2018, almost three-quarters of Poles (72\%) were still reluctant to relocate refugees from outside Europe. ${ }^{34}$ The attitudes of Poles towards accepting Ukrainian refugees from the areas affected by the conflict developed differently. In mid-2016, 37\% of respondents were against granting refugee status to Ukrainian people. ${ }^{35}$ Therefore, Poles accept giving shelter to their eastern neighbours much more often than to refugees from outside Europe. Distance to foreigners has become a guideline for integration policy and shows its limitations.

Although the existing legal solutions relating to the integration of beneficiaries of international protection did not change, the new government began to modify the current migration policy. Refugees were not accepted as part of the relocation agreed in negotiations between the EU Member States. However, the return and settlement in Poland by people of Polish origin was facilitated. ${ }^{36}$ There was an improvement in integration in the field of education as a result of the introduction of intercultural training for teachers and free courses for immigrant students. On the other hand, it became more difficult to obtain a permanent residence permit. In 2018, immigrants applying for permanent residence were required to certify their knowledge of Polish at the B1 level and prove that they have a stable and regular source of income. In 2019, a draft of a new migration policy was developed. It postulated, inter alia, the improvement in the integration of foreigners. The document entitled Polityka Migracyjna Polski (Polish Migration Policy) prepared by the Ministry of the Interior and Administration of June 10, 2019, emphasized that the immigration and integration paradigm requires a reevaluation towards the concept of a leading culture (Leitkultur concept by Bassam Tibi). ${ }^{37}$

${ }^{33}$ Currently, these issues do not arouse such emotions as a few years ago.

34 CBOS, Stosunek Polaków i Czechów do uchodźców, Komunikat z Badań, no. $87 / 2018$.

35 CBOS, Stosunek Polaków do przyjmowania uchodźców, Komunikat z Badań, no. $24 / 2016$.

36 Ustawa z dnia 13 maja 2016 r. o zmianie ustawy o Karcie Polaka oraz niektórych innych ustaw (Dz.U. 2016 item 753); Ustawa $z$ dnia 7 kwietnia 2017 r. o zmianie ustawy o repatriacji oraz niektórych innych ustaw (Dz.U. 2017 item 858).

37 Polityka migracyjna Polski, Project of June 9, 2019, Team for Migration, pp. $42-43$. 
Obtaining the right of permanent residence in the territory of the Republic of Poland became dependent on the full integration of the foreigner with Polish society. Integration is understood as making a foreigner as independent as possible and comprises activities addressed to both a foreigner and their social environment. Obligatory integration programs (courses), abundant with assimilation elements, are not to be free of charge and should result in unconditional acceptance of Polish legal, cultural and moral norms. The objective of the Polish integration policy is the assimilation of foreigners. The assimilation of a foreigner is considered as "reaching a state in which an integrated foreigner understands and recognizes the values existing in Poland, including ideological and religious values, accepts and adopts them as their own, and rejects values that would pose a threat to social cohesion and universal security in Poland". ${ }^{38}$ The possibility of obtaining Polish citizenship became dependent on the full assimilation of the foreigner into Polish society. However, work on the new strategy has not yet been completed. As a result, Poland still does not have an integration strategy or policy document.

The scale of challenges facing Poland is illustrated by the Migrant Integration Policy Index (MIPEX). In 2015, Poland ranked 32nd out of 38 countries researched on immigrant integration policies. Out of the EU countries, only five countries (Malta, Slovakia, Lithuania, Cyprus and Latvia) ranked lower. After five years (in 2020), the overall MIPEX index fell by 1 percentage point (to 40). Poland ranked 44th out of 52 countries researched and was classified as a country displaying a slightly unfavorable approach to immigrants. Out of the EU countries, only four countries (Croatia, Slovakia, Latvia, Lithuania) got a lower rate. The Polish approach to integration was classified by MIPEX in the 2020 report as only "equality on paper". Restrictive Polish policy may favour exclusion and hinder integration..$^{39}$ As stated in the MIPEX report, compared to other Visegrad countries, Poland, in general, seems to adopt a policy similar to Slovakia and Hungary. In contrast, integration policy in the Czech Republic is better developed. ${ }^{40}$ The 2019 country report on the functioning of various areas of integration policy towards immigrants under international protection emphasized that in Poland there is a clear discrepancy between the fairly well-rated legal framework and the very

38 Ibidem, p. 38.

39 One of the important dimensions of integration is the possibility for migrants to participate in political life. In Poland, such a possibility is limited, and Polish law in this respect is one of the most restrictive in Europe.

${ }^{40}$ Migrant Integration Policy Index 2020, https://www.mipex.eu (access 2.12.2020). 
low-rated implementation. Although the report focuses on the situation of beneficiaries of international protection, many integration challenges are also common to other immigrant groups, including economic migrants. ${ }^{41}$

It should be noted that Polish large cities have recently taken steps that apply to the definition of integration as a two-way process and are following the path of their Western European counterparts. ${ }^{42}$ Terms such as intercultural diversity, intercultural dialogue or diversity that have appeared recently in Western European cities are used in Polish cities to define the immigrant integration policy. However, the lack of coordination and cooperation between central and local institutions calls into question the effectiveness of local action in the long term.

\section{Conclusions}

The results of the analyzes presented in the article show that in Poland, over a short period of time, the approach to immigrant integration evolved from the "abandonment strategy" through "integration" understood as a two-way process of adaptation to the concept of assimilation. Due to the lack of interest of state and local authorities in integration issues (which resulted from the marginal scale of immigration and the lack of strong ethnic and cultural tensions), the Polish model of immigrant integration in the first two decades after 1989 can be characterized as an "abandonment strategy". Nevertheless, mention should be made of the individual integration programs (IPI) introduced in 2000, which became the first stable instrument of the state's integration policy. After Poland gained access to European funds, the solutions proposed at the European level became the model for creating integration activities. In 2013, the definition of integration as a two-way process was adopted. The migration crisis fundamentally changed the approach to integration. The project of the new Polish migration policy of 2019 promoted the concept of civic integration in relation to foreigners applying for the right of permanent residence in Poland. Civic integration programs have restrictive and assimilating character towards immigrants. Obtaining Polish citizenship became dependent on the full assimilation of foreigners by eliminating (minimizing) their dissimilarity in various aspects. The new migration policy proposes

${ }^{41}$ Instytut Spraw Publicznych, $W$ stronę krajowego mechanizmu ewaluacji integracji. Diagnoza sytuacji beneficjentów ochrony międzynarodowej w Polsce, eds. A. Górska, M. Koss-Goryszewska, J. Kucharczyk, Warsaw 2019, p. 11.

42 L. Rajca, The Role of Cities in the Integration of Immigrants in Europe, "Studia Europejskie - Studies in European Affairs", no. 3/2020, pp. 165-181. 
a more active attitude of the state in regulating the integration of immigrants and a more centralized, repressive and bureaucratic integration policy in order to ensure internal security and socio-cultural cohesion, thus satisfying the interests of the Polish society. In terms of approach to integration, Poland is currently in the mainstream of changes taking place in Europe. It should be emphasized, however, that the strategic document of 2019 remains only a draft, and the Polish immigrant integration policy, both at the central and local levels, is at an early stage of development. Ethnic homogeneity, European funds, the migration crisis, the attitudes of Polish society and the nature of immigration to Poland have a strong influence on the policy and practice of integration in Poland.

To sum up, in the last three decades, the Polish immigrant integration policy has not been created using a deliberate, long-term strategy, but rather in an ad hoc, chaotic, dispersed, and rarely evaluated manner. Currently, Poland needs a coherent and comprehensive concept of immigrant integration in the face of the demographic problem and the growing number of immigrants. The integration of economic immigrants does not arouse such controversy as in other European countries, but this does not mean that Poland will not face various migration challenges in the future.

\section{References}

Ambrosini M., Boccagni P., Urban Multiculturalism beyond the 'Backlash': New Discourses and Different Practices in Immigrant Policies across European Cities, "Journal of Intercultural Studies", no. 36(1)/2015, DOI: https://doi.org/10.1080/07256868.2014.990362.

Anthias F., Moving beyond the fanus face of integration and diversity discourses: towards an intersectional framing, "The Sociological Review", no. 61(2)/2013, DOI: https://doi.org/10.1111/1467-954X.12001.

Asylum seekers and beneficiaries of international protection in V4 Countrie. (Updated Report), https://www.isp.org.pl (access 10.10.2020).

Banting K., Kymlicka W., Is There Really a Backlash Against Multiculturalism Policies? New Evidence from the Multiculturalism Policy Index, Universitat Pompeu Fabra, Working Paper Series, no. 14/2012.

CBOS, Stosunek Polaków i Czechów do uchodźców, Komunikat z Badań, no. 87/2018.

CBOS, Stosunek Polaków do przyjmowania uchodźców, Komunikat z Badań, no. 24/2016.

CBOS, Polacy wobec problemu uchodźstwa, Komunikat z Badań, no. 81/2015. Duszczyk M., Pachocka M., Pszczółkowska D., Introduction, in: Relations 
between Immigration and Integration Policies in Europe. Challenges, Opportunities and Perspectives in Selected EU Member States, eds. M. Duszczyk, M. Pachocka, D. Pszczółkowska, Tylor and Francis, London 2020, DOI: https://doi.org/10.4324/9780429263736.

Duszczyk M., Pachocka M., Pszczółkowska D., Conclusion, in: Relations between Immigration and Integration Policies in Europe. Challenges, Opportunities and Perspectives in Selected EU Member States, eds. M. Duszczyk, M. Pachocka, D. Pszczółkowska, Tylor and Francis, London 2020, DOI: https://doi.org/10.4324/9780429263736.

Duszczyk M., Góra M., Active Inclusion of Immigrants in Poland, IZA Discussion Paper, no. 6427, Bonn 2012.

Duszczyk M., Polska polityka imigracyjna a rynek pracy, ASPRA-JR, Warsaw 2012.

European Commission, Communication on Immigration, Integration and Employment, $\operatorname{COM}(2003) 336$ final.

Eurostat, Migration and migrant population statistics/pl, https://ec.europa.eu/ eurostat/statistics-explained/pdfscache/14236.pdf (access 12.12.2020).

Eurostat, Residence permits - statistics on first permits issued during the year, November 2020, https://ec.europa.eu/eurostat/statistics (access 30.12.2020).

Gebhardt D., When the state takes over: civic integration programmes and the role of cities in immigrant integration, "Journal of Ethnic and Migration Studies", no. 42(5)/2016, DOI: https://doi.org/10.1080/1369183X.2015 .1111132 .

GUS, Populacja cudzoziemców w Polsce w czasie COVID-19, https://stat. gov.pl/statystyki (access 10.12.2020).

Grzymała-Kazłowska A., Weinar A., The Polish Approach to Integration, "Canadian Diversity", no. 5(1)/2006.

$W$ strone krajowego mechanizmu ewaluacji integracji. Diagnoza sytuacji beneficjentów ochrony międzynarodowej w Polsce, eds. A. Górska, M. KossGoryszewska, J. Kucharczyk, Instytut Spraw Publicznych, Warsaw 2019.

Joppke C., The Role of the State in Cultural Integration. Trends, Challenges and Ways Ahead, Migration Policy Institute, Washington 2012.

Łodziński S., Szonert M.,„,Niepolityczna polityka”? Ksztaltowanie się polityki migracyjnej w Polsce w latach 1989-2016 (kwiecień), CMR Working Papers, no. 90/148, Warsaw 2016.

Łodziński S., Grzymała-Kazłowska A., Koncepcje, badania i praktyki integracji imigrantów. Doświadczenia polskie w europejskim kontekście, „Studia Migracyjne - Przegląd Polonijny”, no. 37/2011, z. 2(140). 
Okólski M, Wach D., Immigration and integration policies in the absence of immigrants. A case study of Poland, in: Relations between Immigration and Integration Policies in Europe. Challenges, Opportunities and Perspectives in Selected EU Member States, eds. M. Duszczyk, M. Pachocka, D. Pszczółkowska, Tylor and Francis, London 2020 DOI: https://doi. org/10.4324/9780429263736-9.

Oświadczenie Komitetu Badań nad Migracjami PAN, http://www.kbnm. pan.pl/42-uncategorised/109-oswiadczenie-komitetu-badan-nadmigracjami-pan (access 20.12.2020).

Pawlak M., Imitacja przy tworzeniu polskiej polityki integracji cudzoziemców, „Studia Migracyjne - Przegląd Polonijny”, no. 39(3)/2013.

Polityka migracyjna Polski, Project of June 9, 2019, Team for Migration.

Polityka migracyjna Polski - stan obecny i postulowane dziatania. Dokument przyętty przez Radę Ministrów w dniu 31 lipca 2012. MSW, Warszawa 2012.

Ministerstwo Pracy i Polityki Społecznej, Polska polityka integracji cudzoziemców - zatożenia i wytyczne, Projekt, Warszawa 25.09.2013.

Rajca L., The Role of Cities in the Integration of Immigrants in Europe, "Studia Europejskie - Studies in European Affairs", no. 3/2020, DOI: https:// doi.org/10.33067/SE.3.2020.9.

Rajca L., Integracja imigrantów w Polsce w dobie kryzysu migracyjnouchodźczego, „Chorzowskie Studia Polityczne”, no. 10/2015.

Schiller M., Paradigmatic Pragmatism and the Politics of Diversity, "Ethnic and Racial Studies", no. 38(7)/2015, DOI: https://doi.org/10.1080/014 19870.2014.992925.

Szelewa D., Model integracji spotecznej imigrantów z krajów trzecich: dostęp do ustug spotecznych i przeglad polityki spotecznej, Raporty i Analizy, Warszawa 2010.

Ślęzak J., Polityka migracyjna Unii Europejskiej a problem integracji imigrantów w Niemczech, Francji i Holandii, „Cywilizacja i Polityka”, no. 16(16)/2018, DOI: https://doi.org/10.5604/01.3001.0013.1598.

Vertovec S., Towards post-multiculturalism? Changing communities, conditions and contexts of diversity, "International Social Science Journal", no. 61(199)/2010, DOI: https://doi.org/10.1111/j.1468-2451.2010.01749.x.

Urząd do spraw Cudzoziemców, Naptyw cudzoziemców ubiegających sie o objęcie ochrona międzynarodowa do Polski w latach 2009-2015, https:// udsc.gov.pl/statystyki/raporty-specjalne/ochrona-miedzynarodowatrendy/ (access 29.12.2020).

Ustawa z dnia 13 maja 2016 r. o zmianie ustawy o Karcie Polaka oraz niektórych innych ustaw (Dz.U. 2016 item 753). 
Ustawa $\mathrm{z}$ dnia 7 kwietnia 2017 r. o zmianie ustawy o repatriacji oraz niektórych innych ustaw (Dz.U. 2017 item 858).

Ustawa $\mathrm{z}$ dnia 9 listopada 2000 r. o repatriacji (Dz.U. 2000 no. 106 item 1118 with subsequent amendments).

Ustawa z dnia 7 września 2007 r. o Karcie Polaka (Dz.U. 2018 item 1272 i 1669 with subsequent amendments).

Wach D., Ewolucja polskiej polityki integracji cudzoziemców po 1989 roku, in: Polityka migracyjna wobliczu wspótczesnych wyzwań. Teoria i praktyka, eds. H. Chałupczak, M. Lesińska, E. Pogorzała, T. Browarek, Wydawnictwo UMCS, Lublin 2018. 